\title{
Respons Fisiologi Tanaman Cabai (Capsicum annuum) Var. Lembang 1 terhadap Infeksi Fusarium oxysporum pada Umur Tanaman yang Berbeda
}

\section{The Physiological Responses of Chili (Capsicum annuum) Var. Lembang $1^{\text {st }}$ to Fusarium oxysporum Infection on Different Plant Age}

\author{
Himmatul Ulya' Rejeki Siti Ferniah' Sri Darmanti* \\ Program studi Biologi, , Fakultas Sains dan Matematika Universitas Diponegoro \\ *Email: darmantisri@yahoo.co.id
}

Diterima 11 Agustus 2020 / Disetujui 13 September 2020

\begin{abstract}
ABSTRAK
Cabai merah merupakan komoditas hortikultura yang banyak dibudidayakan oleh petani, namun penyakit layu fusarium yang disebabkan oleh infeksi fungi Fusarium oxysporum menjadi kendala utama dalam budidaya. Penelitian ini bertujuan untuk mengkaji respons fisiologi tanaman cabai kultivar Lembang-1 pada umur tanaman yang berbeda terhadap infeksi F.oxysporum. Penelitian menggunakan Rancangan Acak Lengkap (RAL) pola faktorial 2x2. Faktor pertama adalah infeksi F.oxysporum (diinfeksi dan tidak diinfeksi) dan faktor kedua adalah umur tanaman cabai saat infeksi (35 dan 75 hari setelah tanam). Masing-masing perlakuan dengan 3 ulangan. Parameter yang diamati adalah panjang dan lebar porus stomata, kadar pigmen fotosintesis dan pertumbuhan relative tanaman cabai. Data kuantitatif yang diperoleh dianalisis dengan Analysis of Variance (Anova) dilanjutkan dengan uji DMRT pada taraf kepercayaan 95\%. Hasil penelitian menunjukkan bahwa tanaman cabai yang diinfeksi F.oxysporum pada umur 35 SHT lebih responsif dibanding dengan yang diinfeksi pada umur 75 SHT. Respon fisiologinya tanaman cabai yang diinfeksi pada hari ke 35 setelah tanam adalah penyempitan lebar porus stomata sebesar 31,2\%, penurunan kadar pigmen klorofil dan karotenoid sebesar $18 \%$, penurunan tinggi batang $10,4 \%$ dan penurunan panjang akar $15,9 \%$.
\end{abstract}

Kata Kunci: defisiensi air, infeksi fungi, stomata, xylem

\begin{abstract}
Red chili is a horticultural commodity that is widely cultivated by farmers, but fusarium wilt disease caused by infection with Fusarium oxysporum fungus is a major obstacle in cultivation. This study aims to examine the physiological response of chili crops var. Lembang 1 at different crops ages to F.oxysporum infection. The study used a completely randomized design (CRD) with a $2 \times 2$ factorial pattern. The first factor was F.oxysporum infection (infected and not infected) and the second factor was the age of the chili crops at infection (35 and 75 days after planting). Each treatment with 3 replications. The parameters observed were the length and width of the stomata porus, the levels of photosynthetic pigments and the relative growth of chili crops. The quantitative data obtained were analyzed by Analysis of Variance (Anova) followed by the DMRT test at the 95\% confidence level. The results showed that chili plants infected with F.oxysporum at the age of 35 SHT were more responsive than those infected at the age of 75 SHT. The physiological response of the infected chili cropa on the 35 th day after planting was $31.2 \%$ narrowing of the porus stomata width, $18 \%$ reduction in chlorophyll and carotenoid pigment levels, $10.4 \%$ reduction in stem height and $15.9 \%$ reduction in root length.
\end{abstract}

Keywords: water deficiency,fungi infection, stomata, xylem 


\section{PENDAHULUAN}

Cabai merah merupakan salah satu dari komoditas hortikultura penting yang banyak dikonsumsi oleh masyarakat Indonesia. Cabai merah memiliki peran penting dalam meningkatkan ekonomi petani di Indonesia. Menurut Mariyono dan Sumarno (2015), karena menanam capai dianggap lebih menguntungkan, maka petani yang berada di wilayah penghasil utama cabai di Indonesia memilih menanam cabai dibandingkan komoditas pertanian lainnya. Meskipun petani telah menanam cabai secara intensif, namun masih banyak kendala teknis dan non-teknis yang mengganggu proses budidaya cabai. Kendala tersebut antara lain adalah sistem budidaya, cuaca, ketersediaan fasilitas dan infrastruktur, serta hama dan penyakit. Salah satu penyakit yang yang menjadi kendala serius pada produksi cabai adalah penyakit layu pembuluh yang disebabkan oleh Fusarium oxysporum (Nesme et al, 2010).

Layu Fusarium adalah penyakit tular tanah yang menyerang dan merusak bagian xylem tanaman inang. Kerusakan xylem disebabkan karena fungi F.oxysporum dapat menghasilkan enzim pektolitik yang dapat merusak struktur dinding sel xylem (Okungbowa dan Shittu, 2016). Mikrokonidia $F$. oxysporum berbentuk bulat ginjal dengan ukuran 7,5-16,25 dan 2,5-4,5 $\mu$ m (Hussain et al, 2012), sedangkan diameter xylem tanaman cabai berukuran 56-109 $\mu \mathrm{m}$. Ukuran mikrononidia yang lebih kecil dibanding diameter sel xylem tersebut memungkinkan mikrokonidia dengan mudah memasuki saluran xylem dan dibawa secara vertikal melalui aliran air (Kulkarni dan Phalke, 2009). Selanjutnya mikrokonidia akan tumbuh membentuk hifa dan menyumbat saluran xylem (Kant et al, 2011). Menurut Ozkan dan Kulak (2013), sumbatan saluran xylem oleh hifa tersebut akan menghambat transportasi air dan nutrisi ke bagian atas tanaman. Hal tersebut menyebabkan bagian tanaman yang tidak mendapatkan nutrisi akan rusak dan tidak dapat berfungsi secara normal, sehingga menyebabkan organ tanaman tidak berkembang secara normal dan tanaman tidak dapat tumbuh dengan baik.

Fungi $F$. oxysporum dapat menginfeksi tanaman pada semua tingkat umur, baik selama persemaian hingga fase vegetatif dan generatif (Arik, 2017). Fungi fusarium yang menyerang tanaman muda dapat menyebabkan kematian mendadak karena gejala layu terjadi lebih cepat akibat sel-sel yang masih rentan terhadap serangan patogen (Gongara-Canul dan Leandro, 2011), tetapi pada tannaman dengan kondisi tertentu, dapat beradaptasi dengan baik karena sel-selnya masih meristematik sehingga regenerasi sel masih tinggi. Infeksi fusarium pada tanaman dewasa masih biasa menyebabkan pertumbuhan, meskipun pertumbuhannya terhambat karena sel-sel tanaman dewasa lebih kompak dan dapat mengekspresikan gen pertahanan yang lebih baik (Beck, 2010).

Cabai kultivar Lembang 1 merupakan salah satu kultivar cabai merah yang banyak ditanam di Indonesia. Kultivar Lembang 1 ini dikeluarkan oleh Badan Penelitian dan Pengembangan Pertanian (Balitbang) pada tahun 2008 (Anonim, 2017). Kultivar Lembang 1 memiliki produki yang tinggi, yaitu sekitar 10 ton / ha dan memiliki ketahanan terhadap hama pengisap daun (Thrips) dan penyakit Anthracnose, tetapi belum diteliti bagaimana resistensi kultivar Lembang 1 terhadap layu fusarium (Anonim, 2001). Dalam penelitian ini dikaji mekanisme respon fisiologi tanaman cabai terhadap infeksi Fusarium oxysporum, pada umur tanaman yang berbeda saat terinfeksi.

\section{METODE PENELITIAN}

Penelitian dilaksanakan di Kebun Penelitihan, Laboratorium Biologi Struktur dan Fungsi Tumbuhan dan Laboratorium Bioteknologi Departemen Biologi Fakultas Sains dan Matematika Universitas Diponegoro. Waktu penelitian Desember 2018 - April 2019. Bahan yang digunakan dalam penelitian ini adalah benih cabai kultivar Lembang 1 diperoleh dari Balitbang. Alat utama yang digunakan adalah Spektrofotometer UV-Vis dan fotomikrograf. Penelitian menggunakan Rancangan Acak Lengkap (RAL) pola faktorial $2 \times 2$. Faktor pertama adalah infeksi F.oxysporum (diinfeksi dan tidak diinfeksi) dan faktor kedua adalah umur tanaman cabai saat infeksi (35 dan 75 hari setelah tanam). Masingmasing perlakuan dengan 3 ulangan. 


\section{Persiapan Media dan Benih}

Persiapan kultur fungi Fusarium oxysporum murni dalam media Potato Dextrose Agar (PDA). Persiapan media tanam. Media tanam disterilkan dengan autoklaf selama 20 menit pada tekanan 15 psi / 1 atm. Persiapan tanaman cabai Lembang 1. Dimulai dengan seleksi benih berdasarkan keseragaman bentuk dan ukuran. Penyemaian benih pada media tanam yang sudah disterilkan, dilakukan dua tahap dengan selisih waktu 40 hari untuk mendaptkan bibi usia 35 hari dan 75 hari pada saat yang bersamaan.

\section{Infeksi F.oxysporum}

Infeksi fungi F.oxysporum ke tanaman melewati jalur penyerapan dari akar. Isolat F.oxysporum dalam media Potato Dextrose Broth (PDB) yang telah berumur seminggu diencerkan dalam aquadest dengan tingkat pengenceran dua kali, dengan jumlah spora $4 \times 10^{6} / \mathrm{mL}$. Tanaman cabai berusia 35 dan 75 HST dibersihkan dari tanah, kemudian disterilkan dengan merendam dalam larutan Bayclin 1\% selama 1 menit, kemudian dibilas dengan aquadest steril selama 1 menit. Beberapa akar lateral tanaman cabai dipotong menggunakan gunting dan kemudian tanaman cabai direndam dalam isolat F.oxysporum dalam PDB selama 20 menit. Tanaman cabai yang telah terinfeksi oleh fungi F.oxysporum kemudian ditanam pada media tanam steril. Penyiraman dilakukan dengan volume dan waktu yang sama untuk semua perlakuan.

\section{Pengukuran Lebar Stomata}

Pengukuran lebar mulut stomata dilakukan berdasarkan prosedur Boso, et al (2016). Cat kuku warna transparan dioleskan pada bagian abaksial daun ke-3 tanaman cabai dan dibiarkan sampai cat kuku kering. Cat kuku diambil dari permukaan daun dengan bantuan selotip warna transparan. Hasil replika kemudian ditempatkan pada objek kaca. Lebar mulut stomata diukur menggunakan fotomikrograf dengan perbesaran 400x.

\section{Pengukuran Kadar Klorofil}

Pengukuran kadar klorofil a, klorofil b, klorofil total, dan karotenoid berdasarkan metode yang digunakan oleh Kumari, dkk (2018). Daun urutan ke lima sebanyak $0,1 \mathrm{~g}$ dihaluskan dan dilarutkan dalam aseton $90 \%$ sebanyak $10 \mathrm{~mL}$. Larutan yang diperoleh disaring dengan kertas saring. Filtrat yang diperoleh diukur absorbansinya dengan menggunakan spektrofotometer UV pada panjang gelombang $480 \mathrm{~nm}, 645 \mathrm{~nm}$, dan $663 \mathrm{~nm}$. Kadar klorofil dan karotenoid dihitung dengan rumus berikut:

$$
\begin{array}{ll}
\text { Korofill a } & : 12,21 \times(\mathrm{A} 663)-2,81 \times(\mathrm{A} 645) \\
\text { Korofill b } & : 20,13 \times(\mathrm{A} 645)-5,03 \times(\mathrm{A} 663) \\
\text { Korofill total } & : 17,3 \times(\mathrm{A} 646)+7,18(\mathrm{~A} 663)
\end{array}
$$

Karotenoid :

$$
\frac{(A 480+(0,114 \times A 663))-(0,638 \times A 646) \times V .103}{112,5 \times W}
$$

Keterangan:

A646 : absorbansi pada panjang gelombang $646 \mathrm{~nm}$ untuk klorofil

A663 : absorbansi pada panjang gelombang $663 \mathrm{~nm}$ untuk klorofil

A480 : absorbansi pada panjang gelombang $480 \mathrm{~nm}$ untuk karotenoid

$\mathrm{V} \quad$ : volume ekstrak $(\mathrm{mL})$

W : berat sampel (grams)

\section{Pengukuran Tinggi Tanaman dan Panjang} Akar

Pengukuran tinggi tanaman dan panjang akar dilakukan daua kali, yaitu saat setelah infeksi atau sebelum ditanam kembali dan 40 hari setelah infeksi (HIS). Hal ini untuk menentukan pertumbuhan relative batang dan akar. Tinggi tanaman diukur dari pangkal batang sampai ujung batang, sedangkan panjang akar diukur dari pangkal batang sampai ujung akar. Pengukuran bobot segar dilakukan dengan menimbang tanaman dengan neraca.

Data kuantitatif yang diperoleh dianalisis menggunakan Analysis of Variant (Anova), dilanjutkan dengan uji lanjut menggunakan Duncan Multi Range Test (DMRT) tingkat kepercayaan $95 \%$.

\section{HASIL DAN PEMBAHASAN}


Hasil penelitian menunjukkan bahwa tidak terdapat interaksi antara perlakuan infeksi dan umur tanaman cabai terhadap lebar porus dan panjang stomata. Infeksi F.oxysporum berpengaruh terhadap lebar porus, namun tidak berpengaruh terhadap panjang stomata (Tabel 1). Infeksi $F$. oxysporum menyebabkan penyempitan porus stomata sebesar 23,4\% dibandingkan dengan stoma pada tanaman cabai yang tidak terinfeksi, sedangkan umur tanaman cabai pada saat infeksi tidak berpengaruh terhadap lebar porus stomata.

Menurut Mukarlina dkk, (2010) setelah menginfeksi akar tanaman, fungi $F$. oxysporum akan membentuk polipeptida berupa toksin likomarasmin yang dapat mengganggu permeabilitas membran sel, asam fusarat dan enzim pektolitik berupa pektinmetilesterase (PME) dan depolimerase (DP). PME dapat menghilangkan metil pada rantai pektin menjadi asam pektat, sedangkan DP memecah rantai asam pektat menjadi poligalakturonida. Fragmen asam pektat yang terbentuk tersebut dapat masuk ke dalam pembuluh xilem dan membentuk massa koloidal dengan bahan non pektin. Hal tersebut dapat menyumbat pembuluh xylem, sehingga mengganggu transport air dan hara melaui xylem. Menururt Silva et al. (2009) penyumbatan tersebut mengakibatkan tanaman yang terinfeksi F.oxysporum akan mengalami defisiensi air, selanjutnya tanaman akan beradaptasi dengan mengurangi lebar porus stoma untuk memgurangi transpirasi. Hal ini juga sesuai dengan hasil penelitan Widyastuti dkk (2013), bahwa tanaman akasia yang terinfeksi F.oxysporum dinding sel penutup stomatanya mengalami kerusakan sehingga sel penutup stoma tersebut menjadi keriput dan lebar porus stomata berkurang. Proses membuka dan menutupnya stomata dalam proses transpirasi berfungsi untuk mengatur keseimbangan air dalam tanaman. Menurut Golec dan Szarejco (2013), membuka dan menutupnya stomata dipengarui oleh kadar air dalam sel-sel penutup stomata. Stomata dalam proses membuka menutupnya tergantung pada perubahan turgor sel penutup stomata. Air yang masuk ke dalam sel penjaga secara osmosis akan menyebabkan tekanan turgor pada sel penjaga. Turgor yang tinggi menyebabkan stomata membuka sebaliknya turgor yang rendah akan menyebabkan stomata menutup. Selain air, fitohormon asam absisat (ABA) juga mempengaruhi proses membuka dan menutupnya sel stomata. ABA sebagai fitohormon stress akan dihasilkan oleh sel-sel parenkim dan terakumulasi di dekat sel-sel penutup stomata. ABA akan menginisiasi penutupan stomata untuk mengurangi transpirasi (Anosheh dkk, 2016).

Tabel 1. Lebar porus dan panjang stoma pada daun tanaman cabai yang dinfeksi fungi F.oxysporum pada saat umur tanaman cabai yang berbeda

\begin{tabular}{|c|c|c|c|c|}
\hline \multirow{2}{*}{ Parameter } & \multirow{2}{*}{ Umur (HST) } & \multicolumn{2}{|c|}{ Perlakuan Infeksi } & \multirow{2}{*}{ Rerata } \\
\hline & & Tidak Diinfeksi & Diinfeksi & \\
\hline \multirow{3}{*}{$\begin{array}{l}\text { Lebar porus } \\
\qquad(\mu \mathrm{m})\end{array}$} & 35 & 9,264 & 6,374 & 7,819 \\
\hline & 75 & 9,708 & 8,162 & 8,935 \\
\hline & Rerata & $9,486^{a}$ & $7,268^{b}$ & $(-)$ \\
\hline \multirow{3}{*}{$\begin{array}{l}\text { Panjang stomata } \\
\qquad(\mu \mathrm{m})\end{array}$} & 35 & 16,703 & 16,297 & 16,500 \\
\hline & 75 & 15,588 & 15,998 & 15,793 \\
\hline & Rerata & 16,145 & 16,147 & $(-)$ \\
\hline
\end{tabular}

Keterangan: Angka yang diikuti huruf yang berbeda pada parameter yang sama, menunjukkan terdapat perbedaan yang nyata dengan uji lanjut DMRT pada tingkat kepercayaan 95\%. HST (Hari Setelah Tanam).

Infeksi fungi F.oxysporum pada tanaman cabai 35 HST dan 75 HST tidak berpengaruh signifikan terhadap panjang stomata. Panjang stomata menunjukkan pertumbuhan stomata dari tanaman cabai dan tidak secara langsung mempengaruhi jumlah air yang ditranspirasikan. Hal ini sesuai dengan pendapat Fanaourakis et al (2009) bahwa dalam proses transpirasi, stoma 
hanya memperlebar celah stomata, sedangkan panjang stomata berada dalam keadaan dan ukuran yang tetap. Panjang stomata tidak menentukan lebar porus. Panjang stomata dipengaruhi oleh pertumbuhan tanaman. Stomata pada daun tua akan lebih panjang dari stomata pada daun muda. Umur tanaman cabai tidak mempengaruhi panjang porus stomata karena sampel daun yang digunakan berada pada urutan daun yang sama, sehingga diasumsikan umur daun sama. Menurut Filter dan Hay (2012), daun yang berada pada nomer yang sama diperkirakan memiliki umur dan fase perkembangan yang sama.

Hasil penelitian menunjukkan tidak terdapat interaksi antara perlakuan infeksi fungi dengan umur tanaman cabai terhadap semua parameter pigmen fotosintetik yang diamati. Infeksi fungi berpengaruh terhadap kandungan klorofil a, klorofil b, klorofil total dan karotenoid, sedangkan umur tanaman tidak berpengaruh terhadap semua kandungan pigmen fotosintetik (Tabel 2).

Tabel 2. Kadar pigmen Fotosintesis tanaman cabai dengan perlakuan infeksi fungi F.oxysporum pada umur yang berbeda

\begin{tabular}{|c|c|c|c|c|}
\hline \multirow[b]{2}{*}{ Parameter } & \multirow{2}{*}{$\begin{array}{l}\text { Umur } \\
\text { Tanaman } \\
\text { (HST) }\end{array}$} & \multicolumn{2}{|c|}{ Perlakuan Infeksi } & \multirow[b]{2}{*}{ Rerata } \\
\hline & & $\begin{array}{l}\text { Tidak } \\
\text { Diinfeksi }\end{array}$ & Diinfeksi & \\
\hline \multirow{3}{*}{$\begin{array}{l}\text { Klorofil a } \\
(\mathrm{mg} / \mathrm{l})\end{array}$} & 35 & 12,132 & 11,091 & 11,611 \\
\hline & 75 & 12,621 & 11,530 & 12,036 \\
\hline & Rerata & $12,337^{\mathrm{a}}$ & $11,311^{\mathrm{b}}$ & $(-)$ \\
\hline \multirow{3}{*}{$\begin{array}{l}\text { Klorofil b } \\
(\mathrm{mg} / \mathrm{l})\end{array}$} & 35 & 6,594 & 5,226 & 5,910 \\
\hline & 75 & 7,649 & 5,584 & 6,616 \\
\hline & Rerata & $7,121^{\mathrm{a}}$ & $5,405^{b}$ & $(-)$ \\
\hline \multirow{3}{*}{$\begin{array}{l}\text { Klorofil } \\
\text { Total } \\
(\mathrm{mg} / \mathrm{l})\end{array}$} & 35 & 18,722 & 16,322 & 17,522 \\
\hline & 75 & 20,187 & 17,112 & 18,649 \\
\hline & Rerata & $19,455^{\mathrm{a}}$ & $16,717^{\mathrm{b}}$ & $(-)$ \\
\hline \multirow{3}{*}{$\begin{array}{l}\text { Karotenoid } \\
(\mu \mathrm{mol} / \mathrm{l})\end{array}$} & 35 & 10,637 & 7,469 & 9,053 \\
\hline & 75 & 11,307 & 9,830 & 10,569 \\
\hline & Rerata & $10,972^{a}$ & $8,650^{\mathrm{b}}$ & $(-)$ \\
\hline
\end{tabular}

Keterangan: Angka yang diikuti huruf yang berbeda pada perlakuan yang sama, menunjukkan terdapat perbedaan yang signifikan dengan uji DMRT pada taraf kepercayaan $95 \%$. HST : Hari Setelah Tanam.

Infeksi fungi F.oxysporum pada tanaman cabai menyebabkan penurunan kadar klorofil a sebesar 8,3\%, klorofil b sebesar 24,1\%, klorofil total $14,1 \%$, dan karotenoid sebesar $21,2 \%$ dibandingkan dengan tanaman cabai yang tidak terinfeksi. Sedangkan umur tanaman cabai waktu diinfeksi tidak berpengaruh terhadap kandungan klorofil a, klorofil b, total klorofil dan karotenoid. Penurunan kadar klorofil dan karotenoid pada tanaman cabai yang diinfeksi pada umur 35 HST lebih tinggi jika dibandingkan dengan tanaman cabai yang diinfeksi pada umur 75 HST. Hal hal terjadi sebagai respon tanaman muda dalam mengatasi defisiensi air. Salah satu faktor yang mempengaruhi kadar klorofil adalah ketersediaan air dalam tanaman. Tanaman yang tumbuh pada media tanam dengan tingkat penyediaan air suboptimal akan mengalami defisiensi air yang dapat mengakibatkan penurunan konsentrasi klorofil per area daun. Menurut Arjenaki dkk (2012) cekaman kekeringan dapat menyebabkan penurunan kandungan klorofil dikarenakan tanaman mensintesis Reactive Oxygen Species (ROS) dalam jumlah berlebih yang dapat merusak klorofil. Hal ini sesuai dengan hasil penelitian Darmanti et al. $(2016,2018)$ bahwa pada tanaman 
kedelai yang mengalami cekaman kekeringan ringan maupun berat terjadi kenaikan kandungan ROS berupa superoksida $\left(\mathrm{O}^{-}\right)$dan hydrogen peroksida $\left(\mathrm{H}_{2} \mathrm{O}_{2}\right)$ serta penurunan kandungan karotenoid. Selain hal tersebut, menurut Nizar et al, (2014) tanaman yang kekurangan air akan meningkatkan sintesis Abscisic Acid (ABA). ABA disintesis melalui jalur asam mevalonat (MVA) dan jalur methylerythritol 4-fosfat (MEP) plastidic. MVA dan MEP juga digunakan untuk sintesis pigmen karotenoid. Peningkatan sintesis ABA ini menyebabkan pembentukan karotenoid terhambat. Hal ini sesuai dengan hasil penelitian Barickman et al (2014) yang menunjukkan bahwa pemberian phytohormon ABA pada tanaman akan meningkatkan kandungan pigmen karotenoid, dikarenakan kebutuhan ABA oleh tanaman sudah terpenuhi. Hal ini menunjukkan bahwa kekurangan air pada tanaman cabai dapat menghambat pembentukan pigmen karotenoid. Menurut Felania (2017), air juga berperan penting dalam proses metabolisme pada tumbuhan cabai, seperti proses biokimia dan aktivitas enzim Enzim berperan dalam biosintesis pigmen fotosintesis. Enzim klorofilase berperan dalam biosintesis klorofil a, enzim klorofil a oksigenase berperan da,lam biosintesis klorofil $b$, sedangkan enzim fitoen sintase dan karotenoid hidroksilase berperan dalam biosintesis karotenoid.

Hasil penelitian menunjukkan terdapat interaksi antara infeksi fungi F.oxysporum dan umur tanaman cabai terhadap penambahan tinggi batang dan panjang akar, tetapi tidak terdapat interaksi terhadap penambahan bobot segar. Infeksi F.oxysporum berpengaruh nyata terhadap penambahan bobot segar, sedangkan umur tanaman tidak berpengaruh terhadap penambahan bobot segar (Tabel 3). Dibandingkan dengan tanaman cabai yang tidak diinfeksi, infeksi F.oxysporum menyebabkan penurunan pertumbuhan relatif tinggi batang sebesar $40 \%$, panjang akar sebesar 64,9\%, dan bobot segar sebesar 54,5\%. Pada tanaman cabai yang diinfeksi pada umur 35 HST terjadi penurunan pertumbuhan relatif tinggi batang $10,4 \%$, panjang akar $15,9 \%$, dan bobot segar $3 \%$, sedangkan yang diinfeksi pada umur 75 hari terjadi penurunan pertumbuhan tinggi batang $9,7 \%$, panjang akar 4\%, dan bobot segar 23,4\%. Hal tersebut menunjukkan bahwa tanaman cabai yang diifeksi pada umur 35 HST lebih responsif terhadap infeksi F.oxysporum dinamdingkan yang diifeksi pada umur 75 HST.

Tabel 3. Pertumbuhan Relatif Tanaman Cabai dengan Pemberian Infeksi fungi F.oxysporum

\begin{tabular}{|c|c|c|c|c|}
\hline \multirow[b]{2}{*}{ Parameter } & \multirow{2}{*}{$\begin{array}{l}\text { Umur } \\
\text { Tanaman } \\
\text { (HST) }\end{array}$} & \multicolumn{2}{|c|}{ Perlakuan } & \multirow[b]{2}{*}{ Rerata } \\
\hline & & $\begin{array}{l}\text { Tidak } \\
\text { Diinfeksi }\end{array}$ & Diinfeksi & \\
\hline \multirow{3}{*}{$\begin{array}{l}\text { Tinggi Batang } \\
(\mathrm{cm})\end{array}$} & 35 & $22,13^{\mathrm{a}}$ & $14,07^{b}$ & 18,28 \\
\hline & 75 & $4,84^{\mathrm{c}}$ & $2,11^{\mathrm{d}}$ & 3,48 \\
\hline & Rerata & 13,49 & 8,09 & $(+)$ \\
\hline \multirow{3}{*}{$\begin{array}{l}\text { Panjang Akar } \\
(\mathrm{cm})\end{array}$} & 35 & $15,29^{\mathrm{a}}$ & $5,80^{\mathrm{b}}$ & 10,55 \\
\hline & 75 & $5,43^{\mathrm{b}}$ & $1,48^{c}$ & 3,46 \\
\hline & Rerata & 10,36 & 3,64 & $(+)$ \\
\hline \multirow{3}{*}{$\begin{array}{l}\text { Bobot } \\
(\mathrm{g})\end{array}$} & 35 & 4,69 & 2,65 & 3,67 \\
\hline & 75 & 3,60 & 1,12 & 2,36 \\
\hline & Rerata & $4,15^{\mathrm{a}}$ & $1,89^{\mathrm{b}}$ & $(-)$ \\
\hline
\end{tabular}

Keterangan: Angka yang diikuti huruf yang berbeda pada parameter yang sama, menunjukkan perbedaan yang signifikan pada uji lanjut DMRT pada taraf kepercayaan $95 \%$. HST : Hari Setelah Tanam.

Pertumbuhan tanaman ditentukan oleh pembelahan dan pembentangan sel. Proses tersebut menggunakan fotosintat sebagai sumber energi.
Kadar air dan nutrisi yang diserap oleh tanaman memiliki peran penting dalam pembentukan fotosintat. Hasil fotosintesis dari daun akan 
diangkut ke seluruh bagian tanaman untuk proses pertumbuhan tanaman (Archad dan Genschik 2009). Menurut Duncan, (2012) pertumbuhan tanaman menggambarkan penambahan biomassa dalam periode tertentu. Proses tersebut membutuhkan air dan unsur hara dalam jumlah tertentu.

Infeksi fungi F.oxysporum menyebabkan penurunan pertumbuhan relatif tanaman cabai karena spora fungi F.oxysporum yang menempel pada akar akan mengkolonisasi di bagian akar dengan cara memperbanyak diri. Spora yang masuk ke dalam akar akan tumbuh membentuk hifa. Kolonisasi fungi menurut Sastrahidayat (2016) adalah proses masuknya sel-sel hifa fungi kedalam sel tanaman inang kemudian tumbuh dengan memanfaatkan nutrisi dalam sel tanaman inang. Fungi yang tumbuh di dalam tanaman inang tersebut akan mengganggu metabolisme dalam tanaman. Selain hal tersebut, Mukarlina dkk, (2010) mengemukakan bahwa gangguan juga disebabkan oleh toksin likomarasmin yang diproduksi oleh fungi $F$. oxysporum akan mengganggu permeabilitas membram sehingga mengganggu proses transport hara melintasi membran sel. Fragmen asam pektat yang terbentuk pada pemecahan rantai asam pektat oleh enzim pektinmetilesterase (PME) dan depolimerase (DP) yang dihasilkan oleh fungi $F$. oxysporum akan membentuk massa koloidal dengan bahan non pektin yang dapat menyumbat pembuluh xylem, sehingga mengganggu transport air dan hara melaui xylem dan tanaman yang terinfeksi F.oxysporum akan mengalami defisiensi air (Silva et al., 2009). Menurut Joshi, (2018) pertumbuhan miselium dalam korteks menyebabkan penyumbatan pembuluh xylem sehingga mengakibatkan stres air dan gangguan penyerapan unsur hara Xylem tidak dapat berfungsi dengan baik, sehingga mengakibatkan transport air dan hara terganggu. Transport air yang terganggu akibat infeksi fungi akan mengakibatkan berkurangnya kandungan air pada daun maupun batang sehingga tanaman menjadi layu dan tidak segar (Nugroho, 2013). Kekurangan air pada tanaman mengakibatkan pertumbuhan daun dihambat untuk mengurangi transpirasi. Pertumbuhan akar juga terhambat karena kehilangan turgor pada daerah pemanjangan akar. Kehilangan turgor mengakibatkan terhambatnya pertumbuhan tanaman dan kelayuan pada tanaman (Campbell dkk, 2003). Semua hal tersebut menyebabkan terjadinya penurunan lebat porus stomata, sintesis pigmen fotosintetik, laju fotosintesis, jumlah fotosintat yang terbentuk dan pada akhirnya akan menurunkan pertumbuhan tanaman.

\section{KESIMPULAN}

Dari penelitian ini dapat disimpulkan bahwa bahwa tanaman cabai yang terinfeksi F.oxysporum pada umur 35 HST lebih responsif dibandingkan dengan tanaman cabai yang terinfeksi pada umur 75 HST . Respons fisiologis berupa penurunan lebar pori stoma $31,2 \%$, penurunan kadar pigmen klorofil dan karotenoid $18 \%$, penurunan tinggi batang $10,4 \%$ dan penurunan panjang akar $15,9 \%$.

\section{DAFTAR PUSTAKA}

Achard, P., dan Genschik, P. 2009. Releasing the brakes of plant growth: how GAs shutdown DELLA proteins. Journal of experimental botany, 60(4), 1085-1092.

Anonymous. 2001. Deskripsi Cabai Kultivar Lembang 1. http://varitas.net/dbvarietas/deskripsi/2199 .pdf. Diakses pada tanggal 29 November 2018.

Anonymous. 2017. Varietas Cabai Lembang 1. http://www.litbang.pertanian.go.id/varietas lone/21/. Diakses pada tanggal 2 Desember 2018.

Arik, U. O. 2017. The Antifungal Effects of Datura stramonium L., D. Metell., D. Innoxia mill. Inflora of Turke. Mugla Journal of Science and Technology, 3(2): 96-103.

Arjenaki, F. G., Jabbari, R., dan Morshedi, A. 2012. Evaluation of Drought Stress on Relative Water Content, Chlorophyll Content and Mineral Elements of Wheat (Triticum aestivum L.) Varieties. International Journal of Agriculture and Crop Sciences, 4(11), 726-729. 
Barickman, T.C., D.A. Kopsell, dan C.E. Sams. 2014. Abscisic Acid Increases Carotenoid and Chlorophyll Concentration in Leaves and fruit of Two Tomato Genotypes. Journal of the American Sosiety for Holticulture Science, 139(3): 261-266.

Beck, Charles B. 2010. An Introduction to Plant Structure and Development: Plant Anatomy for the Twenty-first Century. Cambridge University Press.

Boso, S., P. Gago, V. Alonso-Villaverde, J.L. Santiago, and M.C. Martinez. (2016). Density and Size of Stomata In The Leaves Of Different Hybrids (Vitis Sp.) And Vitis Vinifera Varieties. Vitis, 55: 17-22.

Darmanti S., Santosa, K. Dewi, and L. H. Nugroho (2016). Antioxidative defenses of soybean [Glycine $\max (\mathrm{L}$.) Merr. cv. Grobogan] against purple nutsedge (Cyperus rotundus L.) interference during drought stress. The J. Anim. Plant Sci. 26 (1): 225-232.

Darmanti S., Santosa, K. Dewi, and L. H. Nugroho (2018). Reactive Oxygen Species Accumulations, Phenylalanine Amonialiase Activity and Phenolic Acid Composition of Soybean [Glycine max (L.) Merr.] cv. Grobogan that Exposed to Multiple Stress of Purple Nutsedge (Cyperus rotundus L.) Interference and Drought. The J. Anim. Plant Sci. 28 (1): 244-252.

Duncan, R. 2012. Crops as Enhancers of Nutrient Use. Academic Press.

Fanourakis, D., A. Tapia, E. Heuvelink, and S.M.P. Carvalho. 2009. Cultivar Differences in the Stomatal Characteristics of Cut Roses Grown at High Relative Humidity. Acta Hort, 847: 251-258.

Fitter, A. H., dan Hay, R. K. 2012. Environmental Physiology of Plants. Academic press.

Gongora-Canul, C. C., dan Leandro, L. F. S. 2011. Plant Age Affects Root Infection and Development of Foliar Symptoms of Soybean Sudden Death Syndrome. Plant Disease, 95(3), 242-247.
Hussain, M. Z., Rahman, M. A., Islam, M. N., Latif, M. A., dan Bashar, M. A. 2012. Morphological And Molecular Identification of Fusarium oxysporum Sch. Isolated From Guava Wilt in Bangladesh. Bangladesh Journal of Botany, 41(1), 4954.

Kant, P., Reinprecht, Y., Martin, C. J., Islam, R., dan Pauls, K. P. 2011. 4.59 Disease Resistance/Pathology/Fusarium.

University of Guelph, Guelph, ON, Canada.

Kulkarni, M., dan Phalke, S. 2009. Evaluating Variability of Root Size System and Its Constitutive Traits in Hot Pepper (Capsicum Annum L.) Under Water Stress. Scientia Horticulturae, 120(2), 159-166.

Kumari, R., S. Ashraf, G. K. Bagri, S. K. Khatik, D. K. Bagri, dan D. L. Bagli. 2018. Extraction and Estimation of Chlorophyll Content of Seed Treated Lentil Cropusing DMSO and Acetone. Journal of Pharmacognosy and Phytochemistry, 7(3): 240-250.

Mariyono, J., dan Sumarno, S. 2015. Chilli Production and Adoption of Chilli-Based Agribusiness in Indonesia. Journal of Agribusiness in Developing and Emerging Economies, 5(1), 57-75.

Mukarlina, Khotimah, S., dan Rianti, R. (2010). Uji Antagonis Trichoderma harzianum terhadap Fusarium spp. Penyebab Penyakit Layu pada Tanaman Cabai (Capsicum annum) secara In Vitro. Jurnal Fitomedika 7(2): $80-85$.

Nesme, T., Lescourret, F., Bellon, S., dan Habib, R. 2010. Is the Plot Concept an Obstacle in Agricultural Sciences? A Review Focussing on Fruit Production. Agriculture, ecosystems dan environment, 138(3-4), 133-138.

Nizar, N., L. Li, S. Lu, N. C. Khin, and B. J. Pogson. 2015. Carotenoid Metabolism in Plant: Areview. Molecular Plant 1(8): 68-82.

Okungbowa, F. I., and H. O. Shittu. 2016. Fusarium Wilts: An Overview. Environmental Research Journal 6(2): 83-102. 
Ozkan, A., dan Kulak, M. 2013. Effects of Water Stress on Growth, Oil Yield, Fatty Acid Composition and Mineral Content of Sesamum indicum. J Anim Plant Sci, 23(6), 1686-1690.

Silva, E. C., R. J. M. C. Nogueira, F. H. A. Vale, F. P. Araújo, and M. A. Pimenta. 2009. Stomatal Changes Induced by Intermittent Drought in Four Umbu Tree Genotypes. Brazilian Journal of Plant Physiology 21(1): 33-42.

Widyastuti, S. M., S. Tasik, and Harjono. 2013. Infection Process of Fusarium oxysporum Fungus: A Cause of Damping-Off on Acacia mangium's Seedlings. Agrivita 35(2): 110-118. 